\title{
The Developments of Customary Marine Rights A Case Study in Kei Islands, Southeast Maluku Regency
}

\author{
SRI WAHYU ANANINGSIH \\ Faculty of Law, Diponegoro University
}

\begin{abstract}
This study is aimed to describe the developments and design a concept of recognition of customary marine rights in future in Kei Islands. The method of this study is juridical empirical and the specification of it is descriptive analytical. The data consists of primary data and secondary data. It is analyzed by qualitative method. This study results that the developments of customary marine rights include only in norms as a translation of customary law principles. The developments of it occur in legal subject and legal object of customary marine rights, traditional institutional structure and the customary law of Kei people. There are many factors that influence the developments of customary marine rights such as economic, social, cultural, and political factors. The principles of customary marine rights in Kei Islands are : (a). basically the using customary marine rights just for Kei people, but foreigners can use them too if knowledge of head of village; (b). communal; (c). religious-magical; (d). the highest authority in the head of village; (e).basically the using of customary marine rights only to fulfill the needs of daily living; (f). the using of rights that must be based on customary law. The concept of recognition for customary marine rights in Kei Islands in the future includes the existence legal subjects, legal objects, customary law and the functioning of the traditional institutional structure.
\end{abstract}

Keywords : Customary marine rights, its development and the concept of recognition

\section{INTRODUCTION}

Indonesia is a pluralistic country. Many tribes, cultures and customs are in Indonesia. There are about +80 million people or 1,163 communities of indigenous people who live in Indonesia (AMAN, 2012). Indigenous people are a community of people who have special characteristics. One of special characteristics of them is the high dependence on the natural environment for their live survival and life. The most of the daily living needs of indigenous people take from the natural resources in their land. The dependence on natural resources to fulfill the needs of daily living continues over time from one generation to another generation. From a strong relationship between indigenous

Correspondence: Sri Wahyu Ananingsih, Faculty of Law, Diponegoro University, Semarang, Indonesia.

E-mail: ayu_fhundip@yahoo.com people and their land creates customary rights.

Customary rights ("hak ulayat" in Indonesia) are privilege right of indigenous people. They are combination of rights and obligations of indigenous peoples pertaining to land in the territory (Harsono, 1998). Customary rights are special compensation which attached to indigenous people to control and regulate land and its contents (Sumardjono, 2007). According to The Regulation of Minister State of Agrarian No.5/1999 in Article 2 said that customary rights are authority under the customary law which owned by indigenous people communities to take advantage of natural resources, including land in their region for their life. The existence of this rights comes from the relationship outwardly and inwardly between indigenous people and their environment from generation to generation. Based on that article, it can be said that the customary rights are the rights of indigenous people which regard to their environment in 
which they live and fulfill the needs of daily life. The objects of customary rights are extensive. There are land, sea, plants and animals that live on it. The customary rights which the object is marine called "customary marine rights". This existence of them are less known by public because researchers more study about customary land rights than customary marine rights.

Customary rights is recognized in Article 18B paragraph (2) Constitution of NKRI 1945. It states that the country recognizes and respects to the existence of indigenous people and their rights. The recognition from government will be given as long as the existence of indigenous people and their rights still alive; they are appropriate with the development of Indonesian society and the principles of NKRI. Article 28 I paragraph (3) states that the cultural identity and traditional people rights are respected if they are appropriate with the development and civilization. The guarantee of law protection for indigenous people is basically a natural thing because historically, they have been in existence for a long time before the independent of Indonesian state. After it, indigenous people communities has to be a part of the sub systems of the Republic of Indonesia (NKRI). The recognition must be given by government if they fulfill requirements about that recognition. Conversely, if the requirements can not fulfilled by them, it means their existence is considered no longer. So that the government does not need to give recognition.

The customary marine rights are part of customary rights concept. The customary marine rights are set of rules or practices or management of marine areas and the management of the natural resources. The set of rules of customary marine rights contain rules about the owner of the rights, the types of natural resources which can be exploited, the technique of natural resources exploitation, and the way of community to dominate customary marine region. Therefore, the limitations about these rights are who controls the marine area, the type of resources, utilizing technologies, the level of exploitation and how to dominate the region (Wahyono, 2000).

The community of Kei people acknowledge and recognize customary marine rights in their life. Every village in Kei Islands has customary marine rights. Everyone have same rights to take natural resources in customary marine region in their village. The implementation of the customary marine rights is based on the customary law of Kei. Customary law is the law that grows and derived from customs of its community. Therefore it can be said that customary law is the living law (Abdullah, et al, 2006). Another characteristic of customary law is unwritten form. Their characteristics make customary law dynamic to adapt with social change of community. Therefore customary marine rights are experiencing growth. It adapts social change in community.

The developments of customary marine rights is influenced by several factors. They are economic, social, cultural and political factors. These factors are interrelated between one factor with another factors. Based on the developments of customary marine rights, this study will design a concept of customary marine rights recognition in the future in Kei Islands.

\section{MATERIALS AND METHODS}

This research is a law research that using empirical juridical approach. The location of the research is in Kei Islands, Southeast Maluku Regency. The data are used include the primary and secondary data. The primary data are obtained through interviews with respondents. The secondary data were obtained through library research techniques. The specification of this study is descriptive analysis with analysis qualitative methods.

\section{RESULTS AND DISCUSSION}

\section{Overview of Kei Islands}

Kei Islands is located in the Southeast Maluku Regency. Total its area is 55.932 $\mathrm{km}^{2}$. Kei Islands are divided into Kei Kecil islands and Kei Besar islands. Kei Islands 
consist of land area $\left(4,049 \mathrm{~km}^{2}\right.$ or $7 \%$ from total area) and the sea area $\left(51883 \mathrm{~km}^{2}\right.$ or 93 $\%$ from total area). The approximately 119 pieces of small islands are around Kei Islands. Geographically Southeast Maluku Regency is located at coordinates $131^{\circ} 0^{\prime}-133^{\circ} 5^{\prime}$ east longitude and $5^{\circ} 3^{\prime}-8^{\circ} 0^{\prime}$ south latitude. Kei Islands boundaries are as follows: (a) North is the city of Tual and southern of Papua Province; (b) South is Arafura Sea; (c) West is Banda Sea and the northern part of Tanimbar Islands; (d) East is Aru Islands (The Government of Southeast Maluku Regency, 2009).

They are six sub districts in Kei Islands, Southeast Maluku Regency: (1) Kei Kecil sub district; (2) West Kei Kecil sub district; (3) East Kei Kecil sub district; (4) Kei Besar sub district; (5) North East Kei Besar sub district; (6 ) South Kei Besar sub district.

\section{The Development of Customary Marine Rights in Kei Islands}

\section{Legal subject}

The social structure of Kei people consist of ratschaaps (the leader of a ratschaap is a King). Each ratschaap consists of villages (the leader of village is the head of village). Each village consists of sub villages. A sub village consists of some clan and a clan consists of families. At first, the structure of Kei people used to be genealogical, a society structure which based on the line of the same affinity. But now, the structure of Kei people turns into genealogical territorial. Someone will be recognized as a citizen based on similarity of affinity and residence.

Kei people recognize social stratification in their life. It is like "kasta" in Bali society. They are mel-mel, ren-ren and iri-iri. The social stratification determines their social status and marriage. People from mel-mel group usually are to be government officials or chief; the majority people of ren-ren group usually as workers in private sectors. Some of them to be customary officials. People from iri-iri group are ordinary people. There is a prohibition of marriage between two people of different groups.
In the marriage law, the bridegroom usually gives treasure mating to the bride and her family. There is a change in the form of treasure mating. At the past, they usually gave goods called "benda adat", money and other goods. But now it is very difficult to find the goods called "benda adat" so there is a tendency that people prefer to give money than "benda adat". In the inheritance law, Kei people recognize inheritance system for sons, although there is a tendency that a daughter could be a heir of their parents especially for property rights inheritance.

Every village in Kei Islands has customary marine rights. People in village have authority under customary law to take natural resources in their customary marine region. They have same rights for fulfill their daily needs. Basically, the using of customary marine rights just for fulfill the daily needs. But in practice, Kei people can use customary marine rights for other purposes like fish farming, pearl farming and seaweed farming. They must ask permission from the head of village. In Kei tradition, they must also pay some of money (called "sirih pinang") to the head of village.

Foreigners (people from outside Kei Islands) can use customary marine rights if they take permission to the head of village. If he agrees to give permission, then a foreigner must pay some of money called "sirih pinang" to him. Nowadays, there is a tendency that customary marine rights by foreigners in Kei Islands increase every year. Foreigners interest in doing bussines in Kei Islands because its natural resources are good quality.

Related to the use of customary marine rights by foreigners, after they give some money, then they must make a written agreement with the head of village. The implementation of a written agreement between foreigners and Kei people is different with the condition in the past that they made unwritten agreement. That agreement contains at least about time period and the location using rights. The time period usually more than 10 years. Most of foreigners use 
customary marine rights for cultured pearls and fishes.

\section{The legal object}

Each village in Kei Islands has customary marine region. All of people in a village have the same rights to take natural resources in customary marine region. The head of village has responsibility to manage this region. The customary marine region in Kei is divided into :

a. "Ruat met (waar) soin": is the dry beach area during low tide the highest, the average width of $0-10$ meters from the boundary line of the land with the highest average depth of only 1-3 meters. Shell and small fish usually live in this area;

b. "Meti" : is the limit of low tide area and an area of dry beach at low tide, a depth of about 3-5 meters. This area is usually used by women and children to take seaweed;

c. "Hangar ratan /Hangar soin": is a shallow sea area that never dry at all even though the tide is low. In this area are found many coral reefs with some of variety of fish that live in. It such as ornamental fish and small fish. Hangar ratan is a fishing spot using traditional fishing. Hangar ratan is area with depth around 5-15 meters and a width of about 50-500 yards to several miles of land boundary line. Hangar ratan is a protected area because consumption fishes, lola shell (Trochus niloticus), clams (Tridacna) and cucumber (Holothuria) live in this area;

d. "Nuhan ratan / nuhan soin": is the sea area in which depth reaches 15-100 meters and a width of about 500-1000 meters area of land boundary line. Physically, this region is equal to the hangar ratan area but more fish and coral reefs live in this location. This area is also larger than hangar ratan area. People can use big fishing gear to take fishes;

e. "Faruan" : is the high seas area which has depth of 100-200 meters in width reaches 1000-3000 meters from the boundary line of the mainland. This region is an area of fishing ( fishing ground ). The community is allowed to catch fish using large fishing gear. In addition, this area is a place to collect eggs of fish ( caviar ) throu! 134 the month of May to September each yeal,

f. "Wewuil" : is high seas with depths between 200-300 meters in width area spanning 3000-5000 meters from the boundary line of the mainland;

g. "Wahdaan" : is the high seas area with depths between 300-500 meters in width area spanning 5000-7000 meters from the boundary line of the mainland;

h. "Leat dong" : is the high seas area with a depth of 500-1000 meters in width region include 7000-10000 meters from the boundary line of the mainland;

i. "Walaar entetat" : is the high seas area with a depth of 1000-5000 meters with a wide area spanning 10,000 to 12,000 meters of land boundary line;

j. "Tahit ni wear" : is the area between the high seas with a depth of more than 5000 meters in width infinite expanse of the region or to the boundary waters on the beach or island that is opposite with this area . Tahit ni wear is defined as "water belongs to the sea" (Rahail, 1995).

As a comparation, people in Senamai, Tablasupa and Maruway villages, Papua also divided their sea region into(Yarisetou, 2009):

a. "Akadame" : the sea area that its depth 12 meters;

b. "Kia-kia" : the sea area that its depth between 12 meters until 25 meters;

c. "Nau Koti" : the sea area with a depth 25 meters until 100 meters;

d. "Beta Nau" : the sea area that its depth 100 meters until high sea area.

The customary marine region in Kei Islands has changed after regional division process. It is caused by the implementation of regional outonomy. The government of Maluku Tenggara regency has made regional division for three times. In 2000, the Southeast Maluku district divided into Southeast Maluku District and West Southeast Maluku District. In 2003, the 
Southeast Maluku district divided into Southeast Maluku District and Aru Islands. Furthermore on July $10^{\text {th }}, 2007$, the region of Southeast Maluku district devided into Southeast Maluku District and Tual City. As a result of regional division process in 2007, some village in four ratchaaps in Southeast Maluku District divided into Southeast Maluku District and Tual City. They were ratschaap Tual, ratschaap Yarbadang, ratschaap Ohoitel and ratschaap Dullah. it reduced customary marine region and made a change its boundaries.

The authority of Kei people to use customary marine rights is limited from ruat met into nuhan ratan. It means that the region like faruan, wewuil, wahdaan, leat dong, walaar entetat and tahit ni wear are not customary marine region of Kei. They are categorized as the high sea.

The form of Kei Customary Law is unwritten. It consists of customs and Larvul ngabal law. It regulate all about life of Kei people, including the implementation of cutomary marine rights. It has sanction if someone violates customary law. In the past, the form of sanction consisted of fine and physics sanction. But nowadays, mostly the form of sanction are fine. People prefer to pay fine in the form of money than goods.

Kei people have the traditional institutional structure. They consist of the traditional institutional structure in village and the traditional institutional structure in ratchaap (collection of some village). In a village, it is lead by a head of village. In a ratchaap, it is lead by a king. There are 21 kings in the Kei Islands. The traditional institutional structure of Kei has the main task of the issues relating to customary law including solving customary cases. Kei people always take cases in customary court. They believe that customary court can give the best solution to solve cases. Before 1999, a chief lead a court in a village but the position of the chief held by the head of village after ward. It was the impact of regional autonomy. For big cases, a court will be lead by 21 kings. They act as judges in the court. They decide sanction for defendant. If the defendant rejects sanction, the defendant must do customary oath. Kei people still believe that customary oath has a strong magic. If someone tell a lie about something, he will get disaster.

Based on the result of this research, there are developments in customary marine rights in Kei Islands. They are the impact of social change in Kei people. But the developments only in norms as principles translation of customary law. It means that the developments do not influence the existence of customary marine rights in Kei Islands. In other words, customary marine rights still exists in Kei Islands. Kei people recognize and also implement customary marine rights in their daily life.

The customary law is a basic of the customary marine rights. The law come from society, not from the government. The most of elements in this law are customs and the mosty form is unwritten. The Principles of customary law reflect the personality, soul and motto of life from its society. In generally, principles of the customary law are cooperation, communal, religious- magical, cash and concrete. In Kei Islands, that principles of it still alive.

Many factors that affect developments of customary marine rights, among them are economic, social, cultural and political. The fourth factors are interrelated with each other and occur in their life. On economic factors, Kei people try some other business besides fishing in their efforts to fulfill the daily need. For examples seaweed cultivation, fish farming, fish trading etc. This condition gives opportunities to foreigners to enter Kei Islands and use customary marine rights. They enter into Kei carrying their cultures. They affect Kei cultures. This is showed with the development of the form of customary sanction and the form of agreement between foreigners and the head of village. A sanction is manifested in the form of money. Kei people seldom pay sanctions in goods because they think it is not effective and efficient. About agreement, Kei people like to make it in written form. There is no unwritten agreement nowadays. It means the existence of foreigners affect in social factors too. In 
political factors, the influence is showed through process of regional divisions. Since 2000 to 2007 Kei Islands experienced expansion area for three times. Surely the regional division affected boundaries dan reduced the customary marine region of Kei Islands.

\section{The development of the implementation of customary marine rights}

The social changes always affect the law in a community. There were two views in order to see the change of law in a community. The Traditional views said that the change of law occur after changes occur in community. The law has function to certify the new conditions. In the traditional views, the law developed following all events in society. It occurred at a place and always be behind incident. Although the law came after the development of community, the law was expected could accommodate all the new developments in society. The position of law is passive. It tried to adjust social change. The modern views explained that the existence of the law along with the development of society. The law could accommodate any new developments. In this views, the law played an active role as a tool of social engineering so that changes of law could be desired and planned (planed change) in such a way as expected by community (Manan, 2005).

There is a tendency that the use of customary marine rights by foreigners increased. Related to the use of rights by foreigners, the head of village makes a written agreement with foreigners. It is very different custom with the condition in the past that people made agreement in the form of unwritten. Nowadays, the most of sanction is fine and is not physics sanction anymore.

Based on customary marine rights developments, the concept of recognition of customary marine rights in Kei can be formulated as follows. The recognition can be given if the practice is seen, the existence of customary marine rights. It consists of legal subject, legal object, customary law and the functioning of the traditional institutional structure. The principles of customary marine rights in Kei Islands are : (a) basically, the using customary marine rights are just for Kei people, but foreigners can use them too if knowledge of head of village; (b) communal; (c) religious-magical; $\quad$ (d) the hi 135 authority is the head of village; (e) the usc ur customary marine rights only to fulfill the needs of daily living; (f) the use of rights must be based on customary law. The concept of recognition for customary marine rights in Kei Islands in the future includes the existence of the elements: legal subjects, legal objects, customary law and the functioning of the traditional institutional structure. The development of every element is not a problem as long as it does not eliminate the existence of customary marine rights itself.

\section{CONCLUSION}

Developments of customary marine rights just occur in the norms as the principles translated of the customary law. It means that developments are not influence the existence of customary marine rights. The concept of recognition of customary marine rights in Kei can be formulated as follows: legal subject, legal object, customary law and the functioning of the traditional institutional structure. The principles of customary marine rights in Kei Islands are : (a) Kei people and foreigners can use customary marine rights; (b) communal; (c) religious-magical; (d) the highest authority in the head of village; (e) the use of rights only to fulfill the needs of daily life; (f) the use of rights must be based on customary law.

\section{REFERENCES}

Abdullah M.Adli, dkk, 2006, Selama Kearifan adalah Kekayaan: Eksistensi Panglima Laot dan Hukum Adat Laot di Aceh, Keanekaragaman Hayati Indonesia, Jakarta.

AMAN, Masyarakat Adat, tersedia di website http//aman.or.id,1999-2012. 
Harsono Boedi, "Versi Undang-Undang Pokok Agraria tentang Hak Ulayat dan Hak Bersama", Makalah dalam Sarasehan Nasional tentang Peningkatan Akses Rakyat Terhadap Sumber Daya Tanah, Kantor Menteri Negara Agraria/Kepala BPN dan Asosiasi PPAT, Jakarta, 1998.

Sumardjono Maria SW, 2007, Kebijakan Pertanahan Antara Regulasi dan Implementasi, Kompas, Jakarta.

Rahardjo Satjipto, 2009, Hukum dan Perubahan Sosial, Suatu Tinjauan Teoritis serta Pengalaman-Pengalaman di Indonesia, Gema Publishing, Yogyakarta.

Yarisetau Wiklif, 2009, Tiatiki: Konsep dan Praktek, Arika kerja sama dengan Pemerintah Jayapura-Papua.
Manan Abdul, 2005, Aspek-Aspek Pen: Hukum, PrenadaPress, Jakarta.

Pemerintah Kabupaten Maluku Tenggara, 2009, Rencana Pembangunan Jangka Menengah Daerah Kabupaten Maluku Tenggara Tahun 2008-2013.

Wahyono Ary, dkk, 2000, Hak Ulayat Laut di Kawasan Timur Indonesia, Pressindo Press, Yogyakarta.

Rahail JP, 1995, Bat Batang Fitroa Fitnangan, Tata Guna Tanah dan Laut Tradisional Kei, Seri Pustaka Khasanah Budaya Lokal, Yayasan Sejati, Jakarta 
